\title{
Writing Anxiety Among Public And Private Sectors Pakistani Undergraduate University Students
}

\author{
Muhammad Fareed Dar \\ Department of Humanities \\ NED University of Engineering and Technology \\ Imran Khan \\ Faculty of Education and Learning Sciences \\ Iqra University
}

\begin{abstract}
Pakistan is among the countries where number of English language users is on rapid growth. Despite English has been an influential language in Pakistan since its independence, learners face difficulties in almost every area of English language learning: Listening, reading, writing and speaking referring to just basic skills of English language. This study focuses on one of the four basic skills: Writing. It measures levels of writing anxiety of Pakistani undergraduate students while writing essays on various topics in English. In this study, 418 students participated which represents both public and private sector universities. Cheng (2004) SLWAI's instrument was adopted to answer the research questions. Data analysis revealed that majority of the total participants, 61.48 percent has average level of English language writing anxiety. On the other hand, 19.38 percent of the total participants at undergraduate level face high level of English language writing anxiety. Minimum 19.14 percent of the total participants belong to low level of English language writing anxiety. It is interesting to note that both participants from the private and public sector universities experienced average level of writing anxiety. Consequently, English Language Teachers have to adopt/adapt those writing approaches and modify their methods of writing instruction which could help learners decrease their writing anxiety.
\end{abstract}

Key Words: Anxiety Level, Writing, Public \& Private University Students, Pakistan

$$
\begin{aligned}
& \text { تلخيص }
\end{aligned}
$$

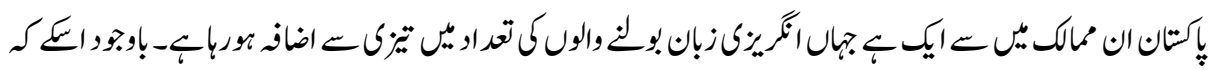

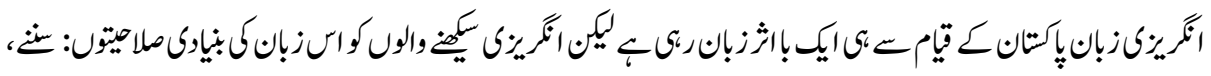

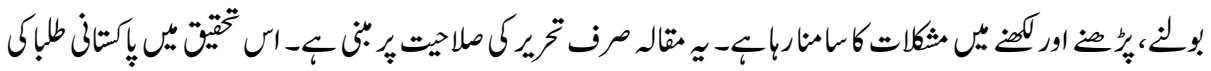

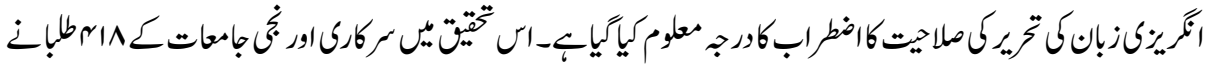

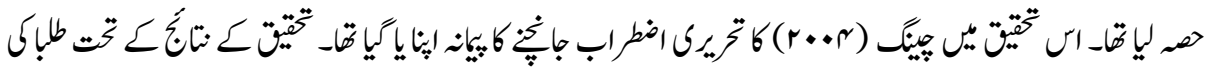

$$
\begin{aligned}
& \text { اكثيت }
\end{aligned}
$$




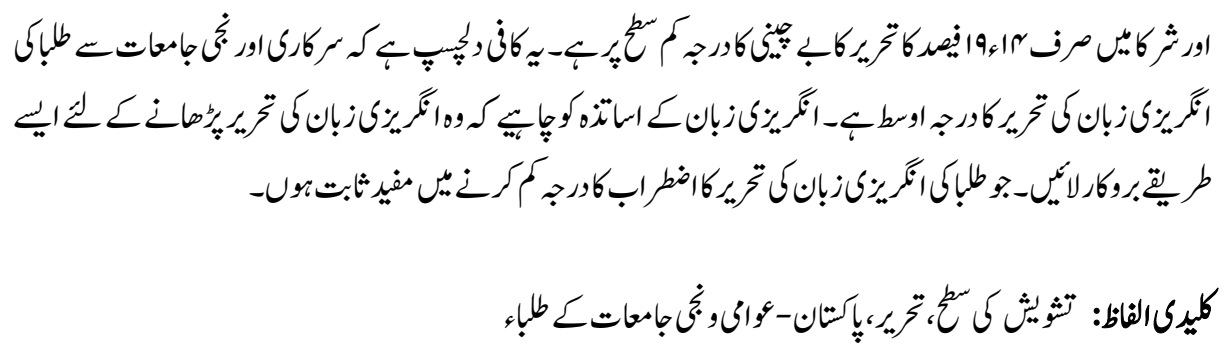

\section{Introduction}

English language enjoys official status in Pakistan and is used for various purposes (Malik, 1996; Mehboob, 2002; Rahman, 2004; Mansoor, 2005; Coleman, 2010;Khan, 2011). It is also medium of instruction and examination along with Urdu in this country. Despite rapid increase of English language speakers in Pakistan, from almost 2\% in 1961 to $49 \%$ in 2003 (EuroMonitor, 2010), the language learners still face difficulties in almost every area: reading, writing, listening, speaking, vocabulary, grammar etc. Writing is one of the key English language skills required in Pakistan, whether it be official communication: letter, emails, memos, reports etc. or educational purposes like: assignments, tests, final written examinations. It is important for Pakistani students to get command of English language writing skills (Hamid, 2007).Pakistani English language learners have weak writing skills at undergraduate and postgraduate levels (Malik, 1996; Mashoori\&Iqbal, 2007;Khan, 2009). Further research is needed in English language writing skills area in Pakistan (Mashoori \& Iqbal, 2007; Mahboob\&Talat 2008; Mashoori, 2010)

The English language community in Pakistan often shares writing related problems (most of the time in informal gatherings, because the research culture in English Language Teaching in Pakistan is still in its early stages). One of the key issues under discussion is writing anxiety (most of the teachers do not use the word anxiety / apprehension; they may use confusion, tension, reluctance to writing etc.). The purpose of this research was tomeasure levels of writing anxiety of undergraduate students in both public and private sector universities.

Writing anxiety has been categories into three levels: high level of anxiety, average/ moderate/ level of anxiety and low level of anxiety. Majority of students in EFL/ESL context face high level of apprehension, followed by moderate/average level further followed by low level of apprehension (Cronwell, Steve, Mckay\& Tonia 1999, Latif2007; Huwari\& Aziz, 2011; Sawalha, Chow \& Foo, 2012).Sawalha etal (2012) revealed that $71.7 \%$ of the sample had high level of apprehension, $5 \%$ had mid-level of apprehension and 23.3\% experienced low level of apprehension. Huwari and Aziz (2011) discovered that majority of the Jordanian postgraduate students $71.8 \%$ faced high writing anxiety, 
followed by moderate level of writing anxiety (26.2\%) and only $1.9 \%$ of the post graduate students experienced low level of anxiety.

Although in many cases as discussed above majority of the participants had high level of writing anxiety, but in the following studies majority of the participants had moderate or low level of writing anxiety. Atay and Kurt (2006) showed in their output that $32 \%$ of the participants were high anxious, $49 \%$ were average anxious and $19 \%$ were low anxious. Erkan and Saban (2011)disclosed that $14.36 \%$ experienced high level of writing apprehension, $38.82 \%$ faced moderate level of writing apprehension, and $46.80 \%$ ) had low level of writing apprehension.

Learners with high level of writing apprehension at graduate level have been reported to have written a paper or proposal that was not completely developed as compare to the learners who had low level of writing apprehension Onwuegbuzie and Collins (2001), as cited in Huwari and Aziz 2011). Philips (1968) states that "highly apprehensive individuals will avoid communication situations or react in some anxious manner if forced into them because they foresee primarily negative consequences from such engagements."(p.42). Hayes, (1981) observes that high apprehensive writers pause more during composing. As reported in Marshall andVarnon (2009) and Faigley et al. Dally and Miller (1975b) observe that high apprehensive students not only have its effects on writing performance but also avoid writing whenever possible; They further go on state that high apprehensive students may even elect out of additional writing courses. Furthermore, writing fear of high apprehensive students may affect on their career selection; they will prefer those careers where less writing is required. At college level highly apprehensive students avoid writing classes. They also receive failing grades for the essays they submit, they have low self-expectations, feel humiliated for the mistakes pointed out by teachers and suffer from 'writer's block' (Buley-Meissner, 1989).

Sawalha, Chow and Foo (2012) observe that apprehensive students had difficulty in bringing their thoughts on paper and find writing classes unfavourable. According to Erkan and Saban (2011) in EFL context high apprehensive students left class room without even trying to write a few sentences in writing section of the examinations. Faigley, Lester and others(1981) believe that high apprehensive students find writing 'unnerving' 'even punishing' (p.2) Huwari and Aziz, 2011 found out that high apprehensive students did not practice writing outside the classroom and they also face difficulties in choosing topics.

On the other hand, Low apprehensive students according to Faigley et al. (1981) do not avoid writing situations, are confident about their writing abilities and frequently enjoy writing. The average apprehension participants have shown mixed characteristics of both high and low apprehensive students. 
Purpose of this research paper was to find out levels of writing anxiety of undergraduate students in public and private sectors in Karachi. The study also intended to see sub levels of writing anxiety: Somatic Anxiety, Avoidance Behavior, and Cognitive Anxiety of total participants, participants from private sector and public sector universities.

\section{Methodology}

Cheng (2004) Second Language Writing Anxiety Inventory (SLWAI) was adopted for this study. The tool was administered with 418 undergraduate students at four universities in spring 2013 in Karachi, Pakistan.Two of the universities were from public sector and two from private sector. $48.3 \%$ of the participants were from two public sector universities and $51.7 \%$ of the participants belonged to private sector universities. $77.8 \%$ participants of the study were male and $22.2 \%$ of the participants were female. $64.6 \%$ of the participants were between $18-20,34.0 \%$ of the participants were between 20-23 years, $01.2 \%$ of the participants were in age group of $24-27$ and only 1 participants $(0.2 \%)$ was above 36 years. $31.3 \%$ of the participants were Bachelors of Engineering (BE) students, $49.3 \%$ of the participants were enrolled in Bachelors of Science (BS) program and $19.4 \%$ participants were Bachelors of Business Administration (BBA) students. 87.8\% of the participants were full time student, $12.2 \%$ of the participants were part time students. Pakistan is a multi-linguistic country, $62.7 \%$ of the participants knew two languages, $24.4 \%$ of the participants could communicate in three languages, $7.4 \%$ of the participants were familiar with four languages, $4.3 \%$ of the participants knew five languages and $1.2 \%$ of the participants were familiar with more than five languages. The study was conducted to answer the following research question and sub questions.

- 'What are the levels of writing anxiety among undergraduate students, when writing in English in Pakistan?'

- What are the levels of writing anxiety of undergraduate students from public sector universities, when writing in English?

- What are the levels of writing anxiety of undergraduate students from private sector universities, when writing in English?

The SALWAI was designed to measure three dimensions of writing anxiety: Somatic Anxiety, Behavioural Anxiety, and Cognitive Anxiety,the first two subscales consist of seven items each and the third one comprises of eight items (Cheng, 2004).The SLWAI (22 items) is a multidimensional Lickert-type scale, developed to measure writing anxiety in English as Second Language (ESL) / English as Foreign language (EFL). It has five possible options ranging from strongly disagree to strongly agree. SLWAI has very good internal consistency with a Cronbach alpha coefficient reported of 0.91 (Cheng, 2004). SALWI was developed with three groups of undergraduate and graduate Taiwnese English majors studying in an EFL context. At the first stage an open-ended writing 
anxiety questionnaire was administered to 67 participants. Responses of the survey helped identify 33 survey items. Secondly, the initial scale was piloted with 56 participants. 22 out of 33 items loaded on three dimensions of writing anxiety: physiological, behavioural, and cognitive in factor analysis the SLWAI was designed to measure. The remaining items that did not load on the three factors were discarded. Further, scores of 421 undergraduate Taiwanese English majors were used to check the validity and reliability of SLWAI (Cheng, 2004). On the basis of the study Cheng (2004) recommends SLWAI as a global valid measure of L2 writing anxiety

The SLWAI was translated into Urdu language (National Language of Pakistan) to facilitate respondents and get accurate responses. The Urdu translation of SLWAI was tested for self-validation, expert validation and pilot-validation. First the researcher translated the 22 items in Urdu very carefully, secondly three experts were consulted for the translation and suggested changes were made and finally, the Urdu translation was given to five raters for inter-coder reliability - agreement of the five raters was calculated with the help of 'Online Kappa Calculator' one January 01, 2013. The Online Kappa Calculator result shows $0.88 \%$ overall agreement among the five raters. Finally, it was administered for pilot-validity with 59 participants.

\section{Data Analysis and Findings}

The data collected from SLWAI was encoded into SPSS 20 version. Descriptive statistics: mean, standard deviation and frequency table were used to calculate levels of students' writing anxiety. Students were categorized into three levels of writing anxiety: high level, moderate level and low level of writing anxiety. Division of the three levels of writing anxiety was based on marks obtained by the students in SLWAI. Students who scored equal to more than mean of the participants in the category plus one standard deviation were placed in high level of writing anxiety category. Students scored equal to or less than mean of the participants in the category minus one standard deviation were termed as low writing anxious. Finally, students who scored between high anxiety and low anxiety limits were kept in moderate anxiety category. Number and percentage of students for each category were calculated with the help of frequency table obtained from SPSS.

\section{Table: 1}

Minimum Score, Maximum Score, Mean Score and Standard Deviation of Total Participants

\begin{tabular}{|l|c|c|c|c|c|}
\hline & N & $\begin{array}{c}\text { Minimum } \\
\text { Score }\end{array}$ & $\begin{array}{c}\text { Maximum } \\
\text { Score }\end{array}$ & M & S D \\
\hline Total Participants & 418 & 56 & 119 & 88.71 & 11.740 \\
\hline
\end{tabular}


Table: 2

Levels of Total Participants' Writing Anxiety

\begin{tabular}{|l|c|c|}
\hline Anxiety Levels & f & \% \\
\hline High level of writing anxiety & 81 & 19.38 \\
\hline Average level of writing anxiety & 257 & 61.48 \\
\hline Low level of writing anxiety & 80 & 19.14 \\
\hline Total & $\mathbf{4 1 8}$ & $\mathbf{1 0 0}$ \\
\hline
\end{tabular}

As mentioned in Table 2, 81(19.38\%) of the total participants face high level of English language writing anxiety. Majority of participants, $257(61.48 \%)$ have average level of English language writing anxiety. Minimum 80 (19.14\%) of the participants belong to low level of English language writing anxiety.

Table: 3

Minimum, Maximum, Mean Score and Standard Deviation of Writing Somatic Anxiety of Total participants

\begin{tabular}{|l|c|c|c|c|c|}
\hline & $\mathbf{N}$ & $\begin{array}{c}\text { Minimum } \\
\text { Score }\end{array}$ & $\begin{array}{c}\text { Maximum } \\
\text { Score }\end{array}$ & M & S D \\
\hline Somatic Anxiety & 418 & 28 & 52 & 39.06 & 5.191 \\
\hline
\end{tabular}

Table: 4

Levels of Somatic Writing Anxiety of Total participants

\begin{tabular}{|l|c|c|}
\hline Anxiety Category & $\mathbf{f}$ & \% \\
\hline High level of somatic writing anxiety & 92 & 22 \\
\hline Average level of somatic writing anxiety & 237 & 57 \\
\hline Low level of somatic writing anxiety & 89 & 21 \\
\hline Total & $\mathbf{4 1 8}$ & $\mathbf{1 0 0}$ \\
\hline
\end{tabular}

The data on somatic writing anxiety of the total participants reveal 92(22\%) of the participants face high level of somatic writing anxiety. Majority of the participants 237 $(57 \%)$ have average level of somatic writing anxiety and $89(21 \%)$ of the participants belong to low level of somatic writing anxiety category.

Table: 5

Minimum, Maximum, Mean Score and Standard Deviation of Writing Avoidance Behavior ofTotal Participants

\begin{tabular}{|l|c|c|c|c|c|}
\hline & $\mathbf{N}$ & $\begin{array}{c}\text { Minimum } \\
\text { Score }\end{array}$ & $\begin{array}{c}\text { Maximum } \\
\text { Score }\end{array}$ & M & S D \\
\hline Avoidance Behavior & 418 & 10 & 32 & 19.37 & 4.296 \\
\hline
\end{tabular}


Table 6

Levels of Avoidance Behavior of Total Participants

\begin{tabular}{|l|c|c|}
\hline Anxiety Category & f & \% \\
\hline High somatic writing anxiety & 70 & 17 \\
\hline Average somatic writing anxiety & 273 & 65 \\
\hline Low somatic writing anxiety & 75 & 18 \\
\hline Total & $\mathbf{4 1 8}$ & $\mathbf{1 0 0}$ \\
\hline
\end{tabular}

Minimum number of the total participants 70 (17\%) face high level of writing Avoidance Behavior. Majority i.e. 273(65\%) of the participants have average level of writing Avoidance Behavior and 75 (18\%) of the participants are low writing Avoidance Behavior anxious.

Table 8

Levels of Cognitive Writing Anxiety of Total Participants

\begin{tabular}{|l|c|c|}
\hline Anxiety Category & f & \% \\
\hline High level of cognitive anxiety & 82 & 20 \\
\hline Average level of cognitive anxiety & 246 & 59 \\
\hline Low level of cognitive anxiety & 90 & 21 \\
\hline Total & $\mathbf{4 1 8}$ & $\mathbf{1 0 0}$ \\
\hline
\end{tabular}

As per above mentioned data and rules for levels of writing cognitive anxiety of the participants $82(20 \%)$ of the total participants are high cognitive writing anxiety conscious. Majority, 246 (59\%) of the participants face average cognitive writing anxiety and $90(21 \%)$ of the participants have low level of cognitive writing anxiety.

\section{Levels of Writing Anxiety of the Participants from Private Sector Universities}

Table 9

Minimum, Maximum, Mean score and Standard Deviation of the Participants from Private Sector Universities

\begin{tabular}{|l|c|c|c|c|c|}
\hline & N & Minimum Score & Maximum Score & M & S D \\
\hline $\begin{array}{l}\text { Participants from Private } \\
\text { Sector Universities }\end{array}$ & 216 & 60 & 119 & 90.07 & 11.779 \\
\hline
\end{tabular}

Table 10

Levels of Writing Anxiety of the Participants from Private Sector Universities

\begin{tabular}{|l|c|c|}
\hline Anxiety Category & f & \% \\
\hline High writing anxiety & 32 & 15 \\
\hline Average writing anxiety & 147 & 68 \\
\hline Low writing anxiety & 37 & 17 \\
\hline Total & $\mathbf{2 1 6}$ & $\mathbf{1 0 0}$ \\
\hline
\end{tabular}


$32(15 \%)$ of the participants from private sector universities have high level of writing anxiety. $147(68 \%)$ of the participants from private sector universities are average writing anxious. $37(17 \%)$ of the participants from private sector universities face low level of writing anxiety.

\section{Table 11}

Minimum, Maximum, Mean Score and Standard Deviation of Writing Somatic Anxiety of the Participants from Private Sector Universities

\begin{tabular}{|l|c|c|c|c|c|}
\hline & N & $\begin{array}{c}\text { Minimum } \\
\text { Score }\end{array}$ & $\begin{array}{c}\text { Maximum } \\
\text { Score }\end{array}$ & M & S D \\
\hline Somatic Anxiety & 216 & 28 & 51 & 39.33 & 5.218 \\
\hline
\end{tabular}

Table 12

Levels of Somatic Writing Anxiety for the Participants from Private Sector Universities

\begin{tabular}{|l|c|c|}
\hline Anxiety Category & f & \% \\
\hline High level of somatic writing anxiety & 40 & 18 \\
\hline Average level of somatic writing anxiety & 133 & 62 \\
\hline Low level of somatic writing anxiety & 43 & 20 \\
\hline Total & $\mathbf{2 1 6}$ & $\mathbf{1 0 0}$ \\
\hline
\end{tabular}

$40(18 \%)$ of the participants from private sector universities face high level of somatic writing anxiety. $133(62 \%)$ of the participants from private sector universities have average level of somatic writing anxiety. 43 (20\%) of the participants from private sector universities are low somatic writing anxious.

Table 13

Minimum, Maximum, Mean Score and Standard Deviation of Writing Avoidance Behavior of the Participants from Private Sector Universities

\begin{tabular}{|l|c|c|c|c|c|}
\hline & N & $\begin{array}{c}\text { Minimum } \\
\text { Score }\end{array}$ & $\begin{array}{c}\text { Maximum } \\
\text { Score }\end{array}$ & M & S D \\
\hline $\begin{array}{l}\text { Avoidance Behavior Private } \\
\text { sector universities }\end{array}$ & 216 & 10 & 32 & 19.60 & 4.305 \\
\hline
\end{tabular}

Table 14

Levels of Writing Avoidance Behavior of the Participants from Private Sector

Universities

\begin{tabular}{|l|c|c|}
\hline Anxiety Category & f & \% \\
\hline High level of Writing Avoidance Behavior & 38 & 18 \\
\hline Average level of Writing Avoidance Behavior & 139 & 64 \\
\hline Low level of Writing Avoidance Behavior & 39 & 18 \\
\hline Total & $\mathbf{2 1 6}$ & $\mathbf{1 0 0}$ \\
\hline
\end{tabular}


$38(18 \%)$ of the participants from the private sector universities are high avoidance behavior anxious. $139(64 \%)$ of the participants from the private sector universities face average level of writing avoidance behavior. 39 (18\%) of the participants from the private sector universities have low level of writing avoidance behavior.

Table 15

Minimum, Maximum, Mean Score and Standard Deviation of Writing Cognitive Anxiety of the Participants from Private Sector Universities

\begin{tabular}{|l|c|c|c|c|c|}
\hline & N & Minimum & Maximum & M & S D \\
\hline Cognitive Anxiety & 216 & 8 & 35 & 22.67 & 5.372 \\
\hline
\end{tabular}

Table 16

Levels of Cognitive Writing Anxiety of the Participants from Private Sector Universities

\begin{tabular}{|l|c|c|}
\hline Anxiety Category & f & \% \\
\hline High level of Cognitive Writing Anxiety & 38 & 18 \\
\hline Average level of Cognitive Writing Anxiety & 132 & 61 \\
\hline Low level of Cognitive Writing Anxiety & 46 & 21 \\
\hline Total & $\mathbf{2 1 6}$ & $\mathbf{1 0 0}$ \\
\hline
\end{tabular}

$38(18 \%)$ of the participants from private sector universities face high level of cognitive writing anxiety. $132(61 \%)$ of the participants from private sector universities are average cognitive writing anxious. $46(21 \%)$ of the participants from private sector universities have low level of cognitive writing anxiety.

Levels of Writing Anxiety of the Participants from Public Sector Universities

Table 17

Minimum, Maximum, Mean Score and Standard Deviation of the Participants from Public Sector Universities

\begin{tabular}{|l|c|c|c|c|c|}
\hline & N & $\begin{array}{c}\text { Minimu } \\
\text { m Score }\end{array}$ & $\begin{array}{c}\text { Maximu } \\
\text { m Score }\end{array}$ & M & S D \\
\hline $\begin{array}{l}\text { Participants from Public Sector } \\
\text { Universities }\end{array}$ & 202 & 56 & 119 & 87.25 & 11.552 \\
\hline
\end{tabular}

Table 18

Levels of Writing Anxiety of the Participants from Public Sector Universities

\begin{tabular}{|l|c|c|}
\hline Anxiety Category & f & \% \\
\hline High level of writing anxiety & 37 & 18 \\
\hline Average level of writing anxiety & 123 & 61 \\
\hline Low level of writing anxiety & 42 & 21 \\
\hline Total & $\mathbf{2 0 2}$ & $\mathbf{1 0 0}$ \\
\hline
\end{tabular}


$37(18 \%)$ of the participants from public sector universities are high writing anxious. 123 $(61 \%)$ of the participants from public sector universities face average level of writing anxiety. 42 (21\%) of participants from public sector universities have low level of writing anxiety.

Table 19

Minimum, Maximum, Mean Score and Standard Deviation of Writing Somatic Anxiety of the Participants from Public Sector Universities

\begin{tabular}{|l|c|c|c|c|c|}
\hline & N & $\begin{array}{c}\text { Minimum } \\
\text { Score }\end{array}$ & $\begin{array}{c}\text { Maximum } \\
\text { Score }\end{array}$ & M & S D \\
\hline $\begin{array}{l}\text { Somatic anxiety Public sector } \\
\text { universities }\end{array}$ & 202 & 28 & 52 & 38.78 & 5.160 \\
\hline
\end{tabular}

Table 20

Levels of Writing Somatic Anxiety of the Participants from Public Sector Universities

\begin{tabular}{|l|c|c|}
\hline Anxiety Category & f & \% \\
\hline High level of somatic writing anxiety & 38 & 19 \\
\hline Average level of somatic writing anxiety & 118 & 58 \\
\hline Low level of somatic writing anxiety & 46 & 23 \\
\hline Total & $\mathbf{2 0 2}$ & $\mathbf{1 0 0}$ \\
\hline
\end{tabular}

$38(19 \%)$ of the participants from public sector universities have high level of somatic writing anxiety. $118(58 \%)$ of the participants from public sector universities are average anxiety anxious. $46(23 \%)$ of the participants from public sector universities face low level of writing anxiety.

Table 21

Minimum, Maximum, Mean Score and Standard Deviation of Writing Avoidance Behavior of the Participants from Public Sector Universities

\begin{tabular}{|l|c|c|c|c|c|}
\hline $\begin{array}{l}\text { Avoidance Behavior } \\
\text { Public sector } \\
\text { universities }\end{array}$ & $\mathrm{N}$ & $\begin{array}{c}\text { Minimum } \\
\text { Score }\end{array}$ & $\begin{array}{c}\text { Maximum } \\
\text { Score }\end{array}$ & $\mathrm{M}$ & $\mathrm{S}$ D \\
\cline { 2 - 6 } & 202 & 10 & 31 & 19.12 & 4.285 \\
\hline
\end{tabular}

Table 22

Levels of Avoidance Behavior for the Participants from Public Sector Universities

\begin{tabular}{|l|c|c|}
\hline Anxiety Category & f & \% \\
\hline High level of Writing Avoidance Behavior & 42 & 21 \\
\hline Average level of Writing Avoidance Behavior & 124 & 61 \\
\hline Low level of Writing Avoidance Behavior & 36 & 18 \\
\hline Total & $\mathbf{2 0 2}$ & $\mathbf{1 0 0}$ \\
\hline
\end{tabular}


$42(21 \%)$ of the participants from public sector universities face high level of writing avoidance behavior. $124(61 \%)$ of the participants from public sector universities have average level of writing anxiety avoidance behavior. 36 (18\%) of the participants from public sector universities are low writing avoidance behavior anxious.

Table 23

Minimum, Maximum, Mean Score and Standard Deviation of Writing Cognitive Anxiety of the Participants from Public Sector Universities

\begin{tabular}{|ll|c|c|c|c|c|}
\hline & N & $\begin{array}{c}\text { Minimum } \\
\text { Score }\end{array}$ & $\begin{array}{c}\text { Maximum } \\
\text { Score }\end{array}$ & M & S D \\
\hline $\begin{array}{l}\text { Cognitive Anxiety } \\
\text { sector universities }\end{array}$ & Public & 202 & 8 & 37 & 22.92 & 5.863 \\
\hline
\end{tabular}

Table 24

Levels of Writing Cognitive Anxiety of the participants from Public Sector Universities

\begin{tabular}{|l|c|c|}
\hline Anxiety Category & f & \% \\
\hline High level of Cognitive Anxiety & 36 & 18 \\
\hline Average level of Cognitive Anxiety & 122 & 60 \\
\hline Low level of Cognitive Anxiety & 44 & 2 \\
\hline Total & $\mathbf{2 0 2}$ & $\mathbf{1 0 0}$ \\
\hline
\end{tabular}

$36(18 \%)$ of the participants from public sector universities face high level of cognitive writing anxiety. $122(60 \%)$ of the participants from public sector universities have average level of cognitive writing anxiety. 44 (22\%) of the participants from public sector universities are low cognitive anxious.

\section{Discussion}

Comparative analysis of somatic writing anxiety, cognitive writing anxiety and avoidance behavior of the total participants reveals that, high level of writing anxiety is the highest in somatic anxiety $22 \%$, followed by $20 \%$ in cognitive anxiety and the lowest among the three is $17 \%$ in avoidance behavior. Secondly, Average level of anxiety is maximum in avoidance behavior (65\%), followed by cognitive anxiety (59\%) and minimum among the three is $(57 \%)$ in somatic anxiety. Finally, the lowest number of participants in low level anxiety category are in avoidance behavior (18\%), followed by $21 \%$ both in somatic and cognitive anxiety.

The percentage of participants in high level of writing anxiety category both from public and private sector is the same $-18 \%$. $62 \%$ of the participants from private sector universities are in average level of writing anxiety category as compared to $61 \%$ of the 
participants from public sector universities. Participants from private sector universities are $1 \%$ more than participants from public sector universities in average level of writing anxiety category. Participants from private sector in low level of writing anxiety are $20 \%$ as compare to $21 \%$ participants from public sector universities. The low level of writing anxiety category possess $1 \%$ more low writing anxious participants from public sector universities than from private sector universities.

The percentage of high level of somatic writing anxiety is $18 \%$ for the participants for private sector universities and 19\% for participants from public sector universities. 1\% Participants from public sector universities is more in high level of somatic writing anxiety than participants from private sector universities. $62 \%$ of the participants from private sector universities are average level somatic writing anxious as compared to 58\% participants from public sector universities. Average level of somatic writing anxiety category has $4 \%$ more participants from private sector universities than public sector universities. $20 \%$ of the participants from private sector universities fall in low level of somatic writing anxiety as compared to $23 \%$ of the participants from public sector universities. Ratio of participants from public sector universities is $3 \%$ more in low level of somatic anxiety category as compared to the participants from private sector universities.

$18 \%$ of the participants from the private sector universities are high avoidance behavior anxious and $21 \%$ of the participants from public sector universities face high level of writing avoidance behavior. Percentage of participants in high level of writing avoidance behavior category is 3\% greater than the participants from private sector universities. $64 \%$ of the participants from the private sector universities face average level of writing avoidance behavior and $61 \%$ of the participants from public sector universities have average level of writing avoidance behavior. In average level of writing avoidance behavior category percentage of participants from private sector universities is $3 \%$ more than participants from public sector universities. $18 \%$ of the participants from both the private sector universities and from the public sector universities have low level of writing avoidance behavior.

$18 \%$ of the participants from both private and public sector universities face high level of cognitive writing anxiety. $61 \%$ of the participants from private sector universities are average cognitive writing anxious and $60 \%$ of the participants from public sector universities have average level of cognitive writing anxiety. Average writing cognitive anxiety category has $1 \%$ more participants from private sector universities as compared to student from public sector universities. $21 \%$ of the participants from private sector universities have low level of writing cognitive anxiety and $22 \%$ of the participants from public sector universities are low writing cognitive anxious. The percentage of low writing cognitive anxious participants from public sector universities is $1 \%$ more than participants from private sector universities. 
Many studies conducted in EFL/ESL context report that maximum participants faced high level of apprehension, followed by moderate/average level further followed by low level of apprehension ( Cronwell, Steve, Mckay\& Tonia 1999, Latif, 2007; Huwari\& Aziz, 2011; Sawalha, Chow \& Foo, 2012), Atay and Kurt (2006) found out that majority of the participants had average level of apprehension same are the finding of this study where majority of the participants experience average level of writing anxiety.

Data analysis reveals that majority of the total participants, $61.48 \%$ has average level of English language writing anxiety. $19.38 \%$ of the total participants at undergraduate level face high level of English language writing anxiety. Minimum 19.14\% of the total participants belong to low level of English language writing anxiety.

Similarly, $15 \%$ of the participants from private sector universities have high level of writing anxiety. $68 \%$ of the participants from private sector universities are average writing anxious. $17 \%$ of the participants from private sector universities face low level of writing anxiety.

Likewise, $18 \%$ of the participants from public sector universities are high writing anxious. $61 \%$ of the participants from public sector universities face average level of writing anxiety. $21 \%$ of participants from public sector universities have low level of writing anxiety.

\section{Conclusions}

It is interesting to note that both participants from the private and public sector universities experienced average level of writing anxiety i.e. $61.87 \%, 68 \%$ and $61 \%$ respectively. On one hand this finding is a good sign as compared to the findings of the other studies held in EFL/ESL contexts where majority of the participants were in high level of writing anxiety category, but on the other hand it is also a challenge for Pakistani undergraduate English Language Teachers to adopt/adapt those writing approaches and methods which could help learners decrease their writing anxiety. The English language teachers should also motivate students and give positive worded feedback on their writings that majority of Pakistani undergraduate students can be brought to low level of writing anxiety. If proper care of undergraduate students' writing skills is not taken they can go to high level of writing anxiety as well.

\section{References}

Atay, D., \& Kurt, G. ( 2006). Perspective teachers and L2 writing anxiety.Asian EFLJournal, 8(4), pp. 100-118.

Buley-Meissner, M.L. (1989). Am I really that bad? Writing Apprehension and Basic Writers, Journal of Basic Writing, vol. 8(2), pp. 3-20. 
Cheng, Y. S. (2004). A measure of second language writing anxiety: scale development and preliminary validation. Journal of Second Language Writing, vol. 13(2004), pp. 313-335.

Coleman. H.(2010). Teaching and learning in Pakistan: The role of language in education. Islamabad: British Council.

Cronwell, Steve, McKay \& Tonai. (1999). Measuring Writing Apprehension in Japan. Retrieved from ERIC database. (ED433712).

Daly, J.A. \& Miller, M.D. (1975b). Further studies on writing apprehension: SAT scores, success expectations, willingness to take advanced courses and six differences. Research in the Teaching of English 9, 250-256.

Erkan, D. Y., \&Saban, A. (2011). Writing performance relative to writing apprehension: Self-efficacy in writing , and attitudes towards writing: a case correlational study in Turkish tertiary-level EFL. The Asian EFL Journal Quarterly, 13(1), 164-192.

Euro Monitor International. The Benefits of the English Language for Individuals and Societies: Quantitative Indicators from Cameroon, Rwanda, Bangladesh and Pakistan. Rep. N.p.: n.p., n.d. retrieved on June 23, 2014, from http://www.teachingenglish.org.uk/sites/teacheng/files/Euromonitor\%20Report\% 20A4.pdf

Faigley, Lester, \& Others. (1981). The Role of writing apprehension in writing performance and competence. Retrieved from ERIC database. (ED200984)

Hamid, A. (2007). Teaching Creative Writing through Pictures (unpublished master's thesis). AllamaIqbal Open University, Islamabad.

Hayes, C.G. (1981). 'Exploring apprehension: composing processes of apprehensive andnon-apprehensive intermediate freshman writers'. ERIC Document, ED210678.

Huwari, I. F., \& Aziz, N. H. A., (2011). Writing apprehension among Jordanian postgraduate students at universitiutara Malaysia .Academic Research International, vol. 1(2), pp. 190-198.

Khan, T. R. (2009). Common Errors made by Pakistani students in written English at college level, SPELT Quarterly, 24(3), 11-18. 
Khan, H. I. (2011).University students' attitudes towards the status of English in Pakistan, SPELT Quarterly, vol. 26(3), pp. 16-26.

Latif, M. A. (2007). The factprs accounting for the Egyptian EFL University students' negative writing affect. Esses Graduate Student Papers in Language \& Linguistics, vol. 9, pp. 57-82.

Mahboob, A. (2002). "No English, No Future!" : Language Policy in Pakistan. In Samuel Gyasi Obeng \& Beverly Hartford (Eds.), Political independence with linguistic servitude : the politics about languages in the developing world, (pp. 1540).United States: Nova Science Publishers.

Mahboob, A., Talaat, M. (2008).English language teachers and teacher education in Pakistan. In Seran Dogancay-Aktunaand Joel Hardman (Eds.), Global English Teaching and Teacher Education: Praxis \& Possibility, (pp. 3-25). Alexandria, USA: TESOL.

Malik, F.J. (1996). The Teaching of English in Pakistan: A study in Teacher Education, Lahore Vanguard Books.

Mansoor, S. (2005). Language planning in higher education a case study of Pakistan. Karachi: Oxford University Press.

Marshall, L. L. \& Varnon, A. W. (2009).Writing apprehension among accounting seniors, The Accounting Educators' Journal, vol. 19, pp. 45-65.

Mashori, G.M. \& Iqbal Z. (2007). Teaching the writing of English: Exploring the impact of process approach on the undergraduate students of shah abdul latif university khairpur, English Language \& Literary Forum, vol. 7, 1-26.

Mashori, G.M. (2010). Practicing process writing strategies in English: an experimental study of pre and post process teaching perceptions of undergraduate students at Shah Abdul Latif University Khairpur. English Language \& Literary Forum, vol. 12 , pp. $25-57$.

Phillips, G.M. (1968). Reticence: Pathology of the normal speaker. Speech Monographs, vol. 35 , pp. 39-49

Rahman, T. (2004).Language and Education: selected documents (1780- 2003). Islamabad: Quaid-i-Azam University 
Sawalha, A., Chow, A.M. S. \& Foo, T. V. (2012).The Effects of Writing Apprehension in English on the Writing Process of Jordanian EFL Students at Yarmouk University, Internatinal Interdisciplinary Journal of Education, vol. 1(1), pp. 6-14.

Muhammad Fareed Dar is Assistant Professor in the Department of Humanities, NED University of Engineering and Technology.

Dr. Imran Khan is Assistant Professor in the Faculty of Education and Learning Sciences, Iqra University. 